\title{
A select list of the publications of Chris Wrigley
}

\section{Books}

\section{As sole or joint author}

A. J. P. Taylor: Radical Historian of Europe (London: I. B. Tauris, 2006), viii +439.

Churchill (London: Haus, 2006), vi + 166 (Portuguese edition, 2008).

British Trade Unions Since 1933 (Cambridge: Cambridge University Press, 2002), viii + IOI.

Winston Churchill: A Biographical Dictionary (Santa Barbara, CA: ABC-Clio, 2002), xxvi +367 .

An Atlas of Industrial Protest in Britain, written with A. Charlesworth, D. Gilbert, A. Randall and H. Southall (London: Macmillan, 1996), xvi + 225 (hardback and paperback).

Lloyd George (Oxford: Blackwell I992), vii + I7I (hardback and paperback).

Arthur Henderson (Cardiff: University of Wales/GPC, 1990), xvi + 2II (hardback and paperback).

Lloyd George and the Challenge of Labour (Brighton: Harvester-Wheatsheaf, 1990), ix + 325.

A. J. P. Taylor: A Complete Annotated Bibliography and Guide to His Historical and Other Writings (Hassocks: Harvester, 1980), ix +707.

David Lloyd George and the British Labour Movement (Hassocks: Harvester, 1976), x + 298 (2nd edition, Gregg Revivals, I992).

\section{As editor}

The Industrial Revolution: Cromford, the Derwent Valley and the Wider World (Cromford: Arkwright Society, 2015), 200.

Britain's Second Labour Government, I929-3I: A Reappraisal, with J. Shepherd and J. Davis (Manchester: Manchester University Press, 20II), 272.

The Emergence of European Trade Unionism, with J.-L. Robert and A. Prost (Aldershot: Ashgate, 2004), 268.

A Companion to Early Twentieth Century Britain (Oxford: Blackwell 2003), xx + 578 . 
A. J. P. Taylor: English History I9I4-1945 (London: Folio, 2000), xxxiv + 638 .

A. J. P. Taylor: Struggles for Supremacy (Aldershot: Ashgate, 2000), vii +395 .

The First World War and the International Economy (Cheltenham: Edward Elgar, 2000), x $+22 \mathrm{I}$.

A. J. P. Taylor: English History 19I4-1945 (London: Folio, 2000), xxxiv +638.

A. J. P. Taylor: Struggles for Supremacy (Aldershot: Ashgate, 2000), ii +395.

A. J. P. Taylor: British Prime Ministers and Other Essays (London: Allen Lane, 1999), xxix + 43I (Penguin paperback, 2000; 2nd edition, Faber \& Faber, 2008).

A. J. P. Taylor: A Century of Conflict, 5 volumes (London: Folio, 1998), xci + 1790.

British Trade Unions 1945-1995 (Manchester: Manchester University Press, 1997), ix + 221.

A History of British Industrial Relations 1939-1979 (Cheltenham: Edward Elgar, 1996), vii + 328.

A. J. P. Taylor: From the Boer War to the Cold War (London: Hamish Hamilton, 1995), xxv + 454 (Penguin paperback, 1996; 2nd edition, Faber \& Faber, 2008).

A. J. P. Taylor: From Napoleon to the Second International (London: Hamish Hamilton, 1993), xxii, 426 (Penguin paperback, I995; 2nd edition, London: Faber \& Faber, 2008).

Challenges of Labour: Central and Western Europe 1917-1920 (London: Routledge, 1993), xi +300 .

On the Move: Essays in Labour and Transport History Presented to Philip Bagwell (London: Hambledon, 199I), xxv + 26I (with John Shepherd), xxv + 26I.

With the International Brigade in Spain, by John Angus (Department of Economics. Loughborough University, 1983; reprinted 1988), viii +20.

A History of British Industrial Relations 19I4-I939 (Brighton: Harvester, 1987), vii + 328 (2nd edition, Gregg Revivals in Economic History, 1993).

Warfare, Diplomacy and Politics: Essays in Honour of A. J. P. Taylor (London: Hamish Hamilton, 1986), v +247 .

William Barnes: The Dorset Poet (Wimborne: Dovecote Press, 1984), xii + 244 (reprinted 1988, 1990 and 2003; University of Massachusetts Press, 1984).

A History of British Industrial Relations I875-19I4 (Hassocks: Harvester, I982; also University of Illinois Press, 1982), xv +229 .

The Working Class in Victorian England, 4 volumes, with Max Goldstrom (Aldershot: Gregg International, 1973), I450.

Editor of The Historian, 1993-98.

Editor of the Gregg Revivals in Economic History Series (26 volumes, 1992-96).

Editor of Ashgate Studies in Labour History (19 volumes, 1998- present).

\section{Journal articles and pamphlets}

'Smoking for King and country: soldiers and cigarettes', History Today (April 20I4), 20-6.

'The Beaverbrook Library, A. J. P. Taylor and the rise of Lloyd George studies', Journal of Liberal History, 77 (winter 20I2).

'The making of the people's William', Journal of Liberal History, 75 (2012), I4-19.

'Gladstone and the London May Day demonstrators', I890, The Historian, IO5 (spring 20I0), 6-IO.

'UK trade unions: some historical perspectives', HHIC Journal, I2 (May 20I0), 4-8.

'Trade unions and the 1964 general election', Contemporary British History, 2I(3) (2007), $325-35$. 
'The branches of the Historical Association 1906-2006', The Historian, II (autumn 2006), $45-57$.

'The portrait of a branch: the Historical Association and history in Nottingham before the Second World War', The Historian, 90 (spring 2006), 36-9.

'Trade unionism in the United Kingdom in the I930s and 1940s', New Perspectives on Modern History, II(3) (March 2006), 24-7.

'A widening embrace: the Pump House People's History Museum', Labour History Review, 70 (3) (2005), pp. 346-50 (with M. Walsh).

'Lloyd George and Gladstone', The Historian, 85 (spring 2005), 8-17.

'Churchill and the trade unions', Transactions of the Royal Historical Society, 6(II) (200I), 273-93.

'William Morris, art and the rise of the British labour movement', The Historian, 67 (2000).

'Womanpower: the transformation of the labour force in the UK and the USA since 1945', ReFresh, 3I (2000), I-4 (with M. Walsh).

'From ASSETT to ASTMS: an example of white-collar union growth in the 1960s', Historical Studies in Industrial Relations, 7 (spring 1999), 54-74.

'A. J. P. Taylor and the Historical Association', The Historian, 55 (1997), 2I-5.

'Hill Top, Beatrix Potter and a tale of much merchandise', The Historian, 52 (1996), I4-17.

'The First World War and liberal values', Liberal Democrat History Group Newsletter, Io (March 1996), I3-I4.

'The red menace? Russian Revolution and Europe', Modern History Review, 5(4) (1994), 20-3; reprinted in P. Catterall and R.Vinen (eds), Europe I9I4-45 (London: Heinemann, 1994), 36-44.

'A. J. P. Taylor: a nonconformist radical historian of Europe', Contemporary European History, 3(2) (1994), I-I4.

'A. J. P. Taylor (1906-1990)', Proceedings of the British Academy, 82 (1993), 493-524.

'Widening horizons? British labour and the Second International', Labour History Review, 58(I) (I993), 8-I3.

'Labour and trade unions in Britain, I880-1939', ReFresh, I3 (199I), I-4; reprinted in A. Digby, C. Feinstein and D. Jenkins (eds), New Directions In Economic and Social History, vol. 2 (London: Macmillan, 1992), 97-IIO.

'Arthur Henderson: from north east industrial conciliation to international multilateral disarmament', North East Labour History Bulletin, 25 (I99I), 5-2.

'Born again socialism', New Socialist, 66 (April 1990), 26-9.

'David Lloyd George, I863-I945', The Historian, 26 (spring 1990), IO-I2.

'Explaining why so many and so few: some aspects of the development of the Labour Party in small towns and rural areas', Journal of Regional and Local Studies, Io(I) (1990), 17-22.

'May days and after' (centenary of red May days), History Today (June 1990), 35-4I.

'Hung county councils', Contemporary Record, 2(6) (1989), 6-8.

'Recent writing on trade unionism in Britain 1875-1939', History Teaching Review Year Book, 2 (1989), 49-53.

'The beginnings of the county council', Leicestershire and Rutland Heritage, 5 (winter 1989), 66-7.

'The French Revolution a hundred years on', New Socialist, 6I (1989), 23-5.

'Cosy co-operation under strain: industrial relations in the Yorkshire woollen industry 1919-1930', Borthwick Paper, 7I (1987), iii + 33.

'Historians and their times: the Webbs, chroniclers of trade unionism', History Today (May I987), 5I-5. 
'Modern labour history and local history', Local History, I5 (April 1987), I8-19.

'Trade unions in Britain I875-1939', The Historian, 9 (winter 1986), IO-I2.

'William Barnes: paternalism and nineteenth century socialism', Somerset and Dorset Notes and Queries, 32(323) (March I986), 483-6.

'Philip Bagwell: an appreciation', Bulletin of the Society for the Study of Labour History, $5 \mathrm{I}(3)$, (November 1986), 6.

'The factory and the community', The Historian, 6 (spring 1985), I5-16.

'I926: social costs of the mining dispute', History Today (November 1984), 5-IO.

'Eric Hobsbawm: an appreciation', Bulletin of the Society for the Study of Labour History, 48 (spring 1984), 2.

'Profile of A. J. P. Taylor', The Historian, 2 (spring 1984), 28.

'The General Strike, 1926: the government's volunteers', The Local Historian, I6(I) (February 1984$), 36-48$.

'The General Strike, 1926: the strikers and their families', The Local Historian, I6(2) (May 1984), 83-9.

'A. J. P. Taylor's major books', in Today's History, supplement to History Today, 33 (June I983), iv.

The General Strike, 1926, in Local History (Surveys in Economics and Social History, Department of Economics, Loughborough University, 1982).

'A. J. P. Taylor at 75', History Today, 3 (April 1981), 49.

'Battersea republicans and the 1902 coronation', Crosscurrents, I (1980), 25-3I.

'Municipal socialism in London', I837-190I, 5 (1980), 52-60.

'Thomas Hardy in 1978', I837-1901, 3 (1978), 57-60.

'William Barnes and the social problem', Proceedings of the Dorset Archaeological Society for 1977, 98 (1977), 19-27.

Battersea Republicans and the 1902 Coronation (London: Battersea and Wandsworth Labour and Social History Group pamphlet, June 1977).

'William Barnes and self-help', I837-I90I, I (1976), I4-I6.

'The burning of the pope in early nineteenth century Dorset', Dorset, 57 (November 1976).

'The improvement of popular festivals', Dorset, 45 (August 1975).

'The Symondsbury harvest home I857', Dorset, 45 (August 1975).

'The myths and realities in the career of John Burns', South Western Star (September 1970).

\section{Essays and chapters in edited collections}

'May days in Britain', in Abby Peterson and Herbert Reiter (eds), The Ritual of May Day in Western Europe: Past, Present and Future (Aldershot: Ashgate, 2016), pp. I3I-59.

'Arthur Henderson', in Charles Clarke and Toby James (eds), British Labour Leaders (London: Biteback, 2015), pp. I24-45.

'Olive Wootton', in Goldmark Gallery, Olive Wootton: Myth and Legend (Hemel Hampstead: Goldmark, 20I5), pp. 3-4.

'Red May days: hopes and fears in Europe in the 1890s', in Michael Davis (ed.), Crowd Actions in Britain and France from the Middle Ages to the Modern World (Basingstoke: Palgrave Macmillan, 2015), pp. 208-22.

'Coalition blues: the Conservatives, the Liberals and Conservative-Liberal coalitions in Britain since I895', in B. W. Hart and R. Carr (eds), The Foundations of the Conservative Party (London: Bloomsbury, 2013), pp. 153-74. 
'The fall of the second Labour government, 1931', in T. Heppell and K. Theakston (eds), How Labour Governments Fall (Basingstoke: Palgrave Macmillan, 20I3), pp. 38-60.

'Gladstone and Labour', in R. Quinault and R. Swift (eds), William Gladstone: New Studies and Perspectives (Aldershot: Ashgate, 20I2), pp. 5I-70.

'Labour dealing with Labour: aspects of economic policy', in J. Shepherd, J. Davis and C. Wrigley (eds), Britain's Second Labour Government, I929-3I: A Reappraisal (Manchester: Manchester University Press, 20II), pp. 37-54.

'Errinerungen, Raume und Demonstranten', in W. Maderthaner and M. Maier (eds), Acht Stunden aber wollen wir Mensch sein: Der I Mai. Geschichte und Geschichten, ist edition (Vienna: Rot, 20IO), pp. 44-9.

'The commemorative urge: the co-operative movement's collective memory', in L. Black and N. Robertson (eds), Consumerism and the Co-operative Movement in Modern British History: Taking Stock (Manchester: Manchester University Press, 2009), pp. 157-73.

'The European context: aspects of British Labour and continental socialism before 1920', in M. Worley (ed.), The Foundations of the British Labour Party: Identities, Cultures and Perspectives, 1900-39 (Aldershot: Ashgate, 2009), pp. 77-93.

'Industrial relations', in N. Crafts, I. Gazely and A. Newell (eds), Work and Pay in Twentieth-Century Britain (Oxford: Oxford University Press, 2007), pp. 203-24.

'Trade unions: rise and decline', in F. Carnevali and J.-M. Strang (eds), Twentieth Century Britain: Economic, Cultural and Social Change, and edition (London: Pearson Longman, 2007), pp. 279-92.

'Expression et mise en scene syndicales a l'heure de la communication: une mutation delicate' (with M. Pigenet, D. Tartakowsky, G. Deneckere and P. Francois), in M. Pigenet, P. Pasture and J.-L. Robert (eds), L'apogee des syndicalismes en Europe occidentale 1960-1985 (Paris: Publication de la Sorbonne, 2005), pp. 227-57.

'Churchill and the trade unions', in D. Cannadine and R. Quinault (eds), Winston Churchill in the Twenty-First Century (Cambridge: Cambridge University Press, 2004), pp. $47-67$.

'Introduction' to A. J. P. Taylor, The Course of German History (London: Routledge, 200I), pp. ix-xv.

'Toil and turmoil: trade unions in a changing economy', in Felipe Fernandez-Armesto (ed.), England 1945-2000 (London: Folio Society, 200I), pp. 215-22.

"Carving the last few columns out of the Gladstonian quarry": the Liberal leaders and the mantle of Gladstone, I898-1929', in D. Bebbington and R. Swift (eds), Gladstone Centenary Essays (Liverpool: Liverpool University Press, 2000), pp. 243-59.

'Counter-revolution and the "failure" of revolution in interwar Europe', in D. Parker (ed.) Revolutions and the Revolutionary Tradition in the West I560-I99I (London: Routledge, 2000), pp. 169-84.

'Organised labour and the international economy', in C. Wrigley (ed.), The First World War and the International Economy (Cheltenham: Edward Elgar, 2000), pp. 20I-I5.

'The war and the international economy', in C. Wrigley (ed.), The First World War and the International Economy (Cheltenham: Edward Elgar, 2000), pp. I-33.

'A harsher economic climate', also statistical appendix and bibliography, in Eric Hobsbawm (ed.), Industry and Empire, 2nd edition (London: Penguin 1999), pp. 298-316 and $325-78$.

'A. J. P. Taylor: five faces and the man', in Attila Pok (ed.), The Fabric of Modern Europe: Studies in Social and Diplomatic History (Nottingham: Astra Press, 1999), pp. 225-38.

'James Ramsay MacDonald I922-31', in K. Jefferys (ed.), Leading Labour: From Keir Hardie to Tony Blair (London: I. B. Tauris, 1999), pp. 19-40. 
'Women in the labour market and in the unions', in J. McIlroy, N. Fishman and A. Campbell (eds), British Trade Unions and Industrial Politics, vol. 2 (Aldershot: Ashgate, 1999), pp. 43-69. Paperback 2nd edition, entitled The High Tide of British Trade Unionism (Pontypool: Merlin, 2007).

'Premiers mai' and 'Les constraintes de la loi' (with G. Deneckere, M-L Goergen, I. Marssolek and D. Tartakowsky; and N. Olszak), in J.-L. Robert, F. Boll and A.Prost (eds), L'Invention des syndicalismes (Paris: Sorbonne, 1997), pp. 199-207, 237-54.

'History: current change and future practice in universities', in D. Kerr (ed.), Current Change and Future Practice (Leicester: Leicester University Press, 1996), pp. I6-24.

'Introduction', 'The Second World War and state interventions in industrial relations 1939-45' and 'Trade union development, 1945-79', in C. J. Wrigley (ed.), A History of British Industrial Relations 1939-1979 (Cheltenham: Edward Elgar, 1996), pp. I-II, I2-43, 62-83.

'The early May Days, I890, I89I and I892', 'The Coal lock-out of I893', 'Industrial protest I940-90', 'Coal disputes manufacturing industry', 'The Winter of Discontent' and 'The 1984-5 miners' strike', in C. J. Wrigley, A. Charlesworth, D. Gilbert, A. Randall and H. Southall (eds), An Atlas of Industrial Protest in Britain 1750-I990 (London: Macmillan, 1996), pp. II2-I5, II6-2I, I77-80, 202-9, 2IO-I6, 217-25.

'The impact of the First World War on the labour movement', in M. Dockrill and D. French (eds), Strategy And Intelligence: British Policy in the First World War (London: Hambledon Press, 1996), pp. 139-59.

'Trade unions, strikes and the government', in R. Coopey and N. Woodward (eds), Britain in the 1970s: The Troubled Economy (London: UCL Press, 1995), pp. 237-9I.

'Introduction', Joy Cross (ed.), Memoirs of A Loughborough Man (Nottingham: University of Nottingham, 1994).

'Now you see it, now you don't. Harold Wilson and foreign policy', R. Coopey, S. Fielding and N. Tiratsoo (eds), The First Wilson Government, 1964-70 (London: Pinter, 1993), pp. $123-35$.

'The state and the challenge of Labour in Britain 1917-1920', in C. Wrigley (ed.), Challenges of Labour: Central and Western Europe 19I7-20 (London: Routledge, I993), pp. 262-88.

'The TUC 1868-1968', in Working for Your Future: The TUC 1868-1993 (London: TUC, 1993), pp. 7-29.

'Chi promosse le prime giornate dei lavoratori in Gran Bretagna', in Andrea Panaccione (ed.), Il l maggio tra passato e future (Rome: Piero Lacaita, 1992), pp. I8I-9I.

'The ILP and the Second International: the early years, I893-I905', in D. James, T. Jowitt and K. Laybourn (eds), The Centennial History of the Independent Labour Party (Keele: Keele University Press, 1992), pp. 299-313.

'Lloyd George and the Labour Party after 1922', in J. Loades (ed.), The Life and Times of Lloyd George (Bangor: Headstart, 1991), pp. 49-69.

'Trade unionists, employers and the cause of industrial peace I9I6-2I', in C. Wrigley and J. Shepherd (eds), On the Move (London: Hambledon Press, I99I), pp. 155-84.

'Trade unions, the government and the economy 1945-89', in T. R. Gourvish and A. O’Day (eds), Britain Since 1945 (Basingstoke: Macmillan, 199I), pp. 59-88.

'Il I maggio del 1890 e del i89i en Gran Bretagna', Andrea Panaccione (ed.), I luoghi e $i$ soggetti (Venice: Marsilio Editori, 1990), pp. 137-66.

'Great Britain', in Andrea Panaccione (ed.), The Memory of May Day (Venice: Marsilio Editori, 1989), pp. 83-I08.

'The First World War and state intervention in industrial relations' and 'The trade unions 
between the wars', in C. Wrigley (ed.), A History of British Industrial Relations I9I4-I939 (Brighton: Harvester Press, 1987), pp. 23-70, 7I-I28.

"'In the excess of their patriotism": The National Party and threats of subversion', in C. Wrigley (ed.), Warfare, Diplomacy and Politics (London: Hamish Hamilton, 1986), pp. 93-II9.

'William Barnes and rural Dorset', in B. Jones (ed.), William Barnes I80I-I886: A Handbook (Dorchester: William Barnes Society, 1986), pp. 25-8.

'The trade unions and the Labour Party', in K. D. Brown (ed.), The First Labour Party (London: Croom Helm, 1985), pp. I29-37.

'The Ministry of Munitions: an innovatory department?', in K. Burk (ed.), War and the State (London: Allen and Unwin, 1982), pp. 32-56.

'The government and industrial relations', in C. Wrigley (ed.), A History of British Industrial Relations I875-I9I4 (Hassocks: Harvester Press, 1982), pp. I35-58.

'Trade unions and politics in the First World War', in B. Pimlott and C. Cook (eds), Trade Unions in British Politics (London: Longman, 1982; 2nd edition, 1991), pp. 69-87.

'How trade unions are organised' and 'What the retail price index means', in G. Terry Page and Michael Armstrong (eds), Personnel and Training Yearbook and Directory 1977 (London: Kogan Page, 1976), pp. 18-22, 27-31.

'The Trade Union and Labour Relations Act 1974', in G. Terry Page and Michael Armstrong (eds), Personnel and Training Yearbook and Directory 1976 (London: Kogan Page, 1975), pp. $47-52$.

'Liberals and the desire for working class representatives in Battersea I886-1922', in K. D. Brown (ed.), Essays in Anti-Labour History (London: Macmillan, 1974), pp. 126-58.

\section{Encyclopaedia and dictionary entries and similar}

'Labour, labour movements, trade unions and strikes (Great Britain and Ireland)', in 19I4-I9I8: International Encyclopedia of the First World War (University of Berlin, April 20I5); available online at http://encyclopedia.I9I4-I9I8-online.net/article/labour_ labour_movements_trade_unions_and_strikes_great_britain_and_ireland (accessed January 2017).

'Churchill and Labour', Churchill Archives website, https://www.chu.cam.ac.uk/archives (accesssed January 20I7).

'William Barnes', 'Ernest Bevin', 'George Brown', 'John Bruce Glasier', 'Katherine Bruce Glasier', 'Arthur Henderson', 'Thomas Mann', 'James Peddie', 'Robert Smillie', 'Sir Ben Turner', in H. C. G. Matthew and B. Harrison (eds), Oxford Dictionary of National Biography (Oxford: Oxford University Press, 2004).

'Unions', in J. Mokyr (ed.), The Oxford Encyclopaedia of Economic History, vol. 5 (Oxford: Oxford University Press, 2003).

'John Burns' and 'John Robert Clynes', in G. Rosen (ed.), Dictionary of Labour Biography (London: Politicos, 200I), pp. 93-4, I24-5.

'Arthur Henderson', in G. Batho (ed.), Durham Biographies (Durham: Durham University, 2000), pp. 68-73.

'British trade unions', 'Margaret Bondfield', 'Arthur Henderson', 'Tom Mann' and 'Ben Tillett', Encarta Encyclopedia $200 \mathrm{I}$ (Redmond, WA: Microsoft, 2000).

'The welfare state', Encarta Encyclopedia I999 (Redmond, WA: Microsoft, 1998).

'The 1997 general election', Encarta Encyclopedia Yearbook 1997 (Redmond: Microsoft, 1997). 
'The Labour Party' and 'The Liberal Party', in Microsoft Encarta Encyclopedia (CD-Rom), World English edition (Redmond, WA: Microsoft, 1997).

'The First World War and liberal values', 'The Liberals and the First World War' and 'David Lloyd George', Social Democrat History Group, 1996, available at the website of the Liberal Democrat History Group, http://www.liberalhistory.org.uk/ (accessed January 20I7).

'Walter Citrine', 'The Clydsiders', 'The General Strike', 'The Taff Vale judgement', 'J. H. Thomas', 'Trade union legislation' and 'TUC', in F. M. Leventhal (ed.), Twentieth Century Britain: An Encyclopedia (New York: Garland, 1995), pp. 152-3, I67, 321-4, 759, 776, 784-9.

'Arthur Henderson' and 'Will Paynter', in K. Robbins, The Blackwell Biographical Dictionary of British Political Life in the Twentieth Century (Oxford: Blackwell, 1990), pp. I99-20I, 309.

'Robert Smillie', in J. O. Baylen and N. Gossman (eds), Biographical Dictionary of Modern British Radicals, vol. 3, part 2 (Hassocks: Harvester, 1989).

'David Landes' and 'A. J. P. Taylor', in J. Cannon (ed.), Dictionary of Historians (Oxford: Blackwell, I988), pp. 232, 406-8.

'Lord Peddie', in D. Jeremy (ed.), Dictionary of Business Biography, vol. 4 (London: Butter' worths, 1985), pp. 604-9. 